\title{
Effects of boron on the mechanical properties of polymethylmethacrylate denture base material
}

\section{Purpose}

The objective of this study was to determine whether the addition of different types of boron (Borax, Boric Acid and Colemanite) to polymethyl methacrylate denture base resin would improve flexural and impact strengths, and surface hardness of polymethyl methacrylate.

\section{Materials and Methods}

Borax, Boric acid, Colemanite were added to heat polymerized polymethyl methacrylate specimens were prepared for flexural strength $(65 \times 10 \times 2.5 \mathrm{~mm})$, impact strength $(50 \times 6 \times 4 \mathrm{~mm})$, and hardness $(20 \times 6 \times 4 \mathrm{~mm})$ tests according to the manufacturers' instructions $(n=10)$. To determine flexural strength of the specimens, they were loaded until failure on a universal testing machine using a three point bending test. Specimens were subjected to the Charpy impact test machine. Hardness of the specimens was measured with an analog shoremeter Shore D. The data were analyzed with Kruskal-Wallis and Mann-Whitney $U$ tests $(\alpha=0.05)$.

\section{Results}

The highest mean flexural strength value was seen in 3\% Borax group and followed by $1 \%$ Colemanite group. In addition, the highest mean impact strength value was recorded in $1 \%$ Colemanite group, and differences between $1 \%$ Colemanite group and control group were found to be statistically significant $(p=0,001)$. Furthermore, there was significant difference in hardness between control group and all other groups $(p<0.001)$.

\section{Conclusion}

The addition of $1 \%$ Colemanite to polymethyl methacrylate improved the mechanical properties of PMMA.

Keywords: Polymethyl methacrylate, Boron, Flexural strength, Impact strength, Surface hardness

\section{Introduction}

Polymethylmetacrylate (PMMA) acrylic resins are used for over 70 years in fabricating complete dentures (1). Though esthetics, low water absorption and surface smoothness are advantages of acrylic resins as denture base material, low mechanical properties are their main disadvantage (24). Due to insufficient mechanical properties, patients wearing removable prosthesis often complain about denture fracture. Many materials and methods are developed to overcome this problem and tried to make restoration better; aluminum and steel plates, using stainless steel wire and lattice, adding metallic powder and particles into acrylic resin, using fiber polyethylene, glass, carbon or graphite with various quantity and forms, adding cross linked vbonding agent and copolymers into resin are the attempts to strengthen denture bases (5-7).

\author{
Ali Kemal Özdemir ${ }^{1}$, \\ Derya Özdemir Doğan² ${ }^{\mathbb{D}}$, \\ Faik Tuğut ${ }^{2}$ (1), \\ Hakan Demir ${ }^{2}$ (D), \\ Hakan Akin ${ }^{3}$
}

ORCID IDs of the authors: A.K.Ö. 0000-0003-1554-4855 D.Ö.D. 0000-0003-2470-9930; F.T. 0000-0002-6323-407X; H.D. 0000-0002-1769-1667; H.A. 0000-0002-4770-4297

*This study was presented in oral presentation at FDI Annual World Dental Congress Istanbul, Turkey 2013

'Department of Prosthodontics, Faculty of Dentistry, Trakya University, Edirne, Turkey

${ }^{2}$ Department of Prosthodontics, Faculty of Dentistry, Cumhuriyet University, Sivas, Turkey

${ }^{3}$ Department of Prosthodontics, Faculty of Dentistry, Sakarya University, Sakarya, Turkey Corresponding Author: Faik Tuğut E-mail: tugut78@hotmail.com Received: 20 August, 2020 Revised: 21 November, 2020 Accepted: 10 December, 2020

DOI: 10.26650/eor.20210132 
Metals do not chemically bond to resins; they also adversely affect the esthetic results of resins. Glass fibers meet the esthetic requirements and can chemically bond to the resin matrix after silane treatment. However, glass fibers are difficult to be mixed homogeneously with resin, thereby resulting in inadequate impregnation of the fibers with the resin (8).

Aluminum borate $\left(\mathrm{Al}_{18} \mathrm{~B}_{4} \mathrm{O}_{33}\right)$ whiskers - first developed in 1980s - offer superior mechanical properties at a low cost (9). However, there are few studies on the use of aluminum borate to strengthen the PMMA prosthesis (10).

Boron, shown by symbol B in the periodic table, has an atomic number of 5, atomic mass of 10.81, and it is an element in between metal and non-metal having semi conducting property. It is the first and the lightest element of $3 \mathrm{~A}$ group in the periodic table. Boron compounds show different properties when reacted with various metal and non-metal elements that provide them to be used in many industries. Boron behaves as a non-metal in its compounds whereas pure boron is an electricity conductor like carbon. Crystalline boron looks like diamond in terms of appearance and optical properties and is nearly as hard as diamond (11). Application areas of boron are glass, ceramic, cleaning and bleaching, flame retardants, agriculture, metallurgy, nuclear applications, boron fibers, aerospace, energy, health and cement. Specialty boron products are boric acid, borax and colemanite (12). Boric acid is mostly used in periodontology in the field of dentistry due to its antimicrobial properties (13). There are also few studies in which boron complexes are incorporated into dental materials for reinforcement $(10,14)$.

In the present study, the reinforcement effects of Borax, Boric Acid and Colemanite in PMMA was investigated by measuring flexural and impact strengths and surface hardness.

The null hypothesis was that the incorporation of Borax, Boric Acid and Colemanite in PMMA resin would no effect on the flexural strength, impact strength and surface hardness.

\section{Materials and Methods}

This study was approved by the Clinical Research Ethics Committee of Cumhuriyet University, Sivas.

\section{Study designing}

In this study, 3 different types of boron [Borax $\left(\mathrm{Na}_{2} \mathrm{~B}_{4} \mathrm{O}_{7}\right)$, Boric acid $\left(\mathrm{H}_{3} \mathrm{BO}_{3}\right)$, Colemanite $\left.\left(\mathrm{Ca}_{2} \mathrm{~B}_{6} \mathrm{O}_{11} .5 \mathrm{H}_{2} \mathrm{O}\right)\right]$ were used. The type, manufacturer, composition of the materials and definitions used in this study are presented in Table 1. For 3 experiments of this study (flexural strength, impact strength and hardness), 360 specimens were prepared ( $n=40$ per each). Specimens were randomly distributed based on the different boron material into three main groups. Each group was then divided into four subgroups $(n=10)$. where one subgroup of each main group was kept without reinforcement (Control), while the other three groups were reinforced with 1,2 and $3 w t \%$ of boron, respectively.

\section{Mold and specimens' preparation}

Following ANSI/ADA specification No.12 (15), metal molds were constructed for a flexural strength test in the desired shape with the dimensions of $65 \times 10 \times 2.5 \mathrm{~mm}$, Impact strength specimens measuring dimensions of $50 \times 6 \times 4 \mathrm{~mm}$ and hardness specimens measuring dimension of $20 \times 6 \times 4$ $\mathrm{mm}$. These specimens were prepared for each acrylic resin according to the manufacturers' recommendations.

Dental wax (Cavex Set Up Wax, Cavex, Netherland) was used to build the shape of the molds and invested in a dental stone (Moldastone, Heraeus Kulzer GmBH, Hanau, Germany) using a metal flask. After the dental stone had set, a wax burnt out procedure was performed through immersing the specimens in boiled water for 5 minutes and then molds were washed out and dried.

The heat-cured specimens were prepared in the molds in denture flasks and cured in a manner similar to that used in conventional denture construction. The heat-polymerized acrylic resin (Paladent, Heraeus Kulzer, Hanau, Germany) was processed according to the manufacturer's recommended polymer: monomer ratio. The temperature was brought up from room temperature to $74^{\circ} \mathrm{C}$, then increased to $100^{\circ} \mathrm{C}$ for 20 min for curing of samples. After cooling, the flask was opened and acrylic specimens were removed and finished.

$2.3 \mathrm{gr}$ of powder with $1 \mathrm{~mL}$ liquid (monomer) of denture base resin was mixed according the manufacturer's instructions. The amount of boron was calculated as a percentage of the powder weight. Required amount of liquid for powder was adjusted. Different boron types was added to the liquid at the rates of $1 \mathrm{wt} \%, 2 \mathrm{wt} \%$ and $3 \mathrm{wt} \%$ respectively, and kept for 5 minutes. Then powder was mixed manually with boron added liquid for 3 minutes and polymerization was achieved by sealing the flask.

Before testing the flexural strength, impact strength and hardness, the specimens were left in distilled water at $37^{\circ} \mathrm{C}$ in a water bath machine for 48 hours (BM 402; Nuve, Ankara, Turkey).

\section{Testing procedures}

Three-point bending test was performed on a universal testing machine (Lloyd LF Plus; Ametek Inc., Lloyd Instruments, Leicester, UK) at a $5 \mathrm{~mm} / \mathrm{min}$ crosshead speed to measure flexural strength. The distance between the supports was adjusted to be $50 \mathrm{~mm}$. The load of fracture was recorded and the flexural strength were calculated using the equation:

$$
\mathrm{FS}=\frac{3 \mathrm{FI}}{2 \mathrm{bh}^{2}}
$$

FS indicates the flexural strength, $\mathrm{F}$ is the load to fracture value measured in Newton $(\mathrm{N})$, I presents the separation distance, and $b$ and $h$ are presented the specimen width and thickness, respectively.

The impact strength was evaluated using the Charpy method for which the specimens were horizontally positioned with a distance of $40 \mathrm{~mm}$ between the 2 fixed supports. The test was performed at room temperature in an impact testing machine (Zwick HIT 5.5, Germany). Charpy method was carried out with $0.5 \mathrm{~J}$ pendulum and a distance between two supporting points of $40 \mathrm{~mm}$. Impact strength of the specimens were calculated by using following formula:

$$
a_{\mathrm{cU}}=\left(E_{\mathrm{c}} / h b\right) 10^{3}
$$


Table 1. Details of different boron materials used

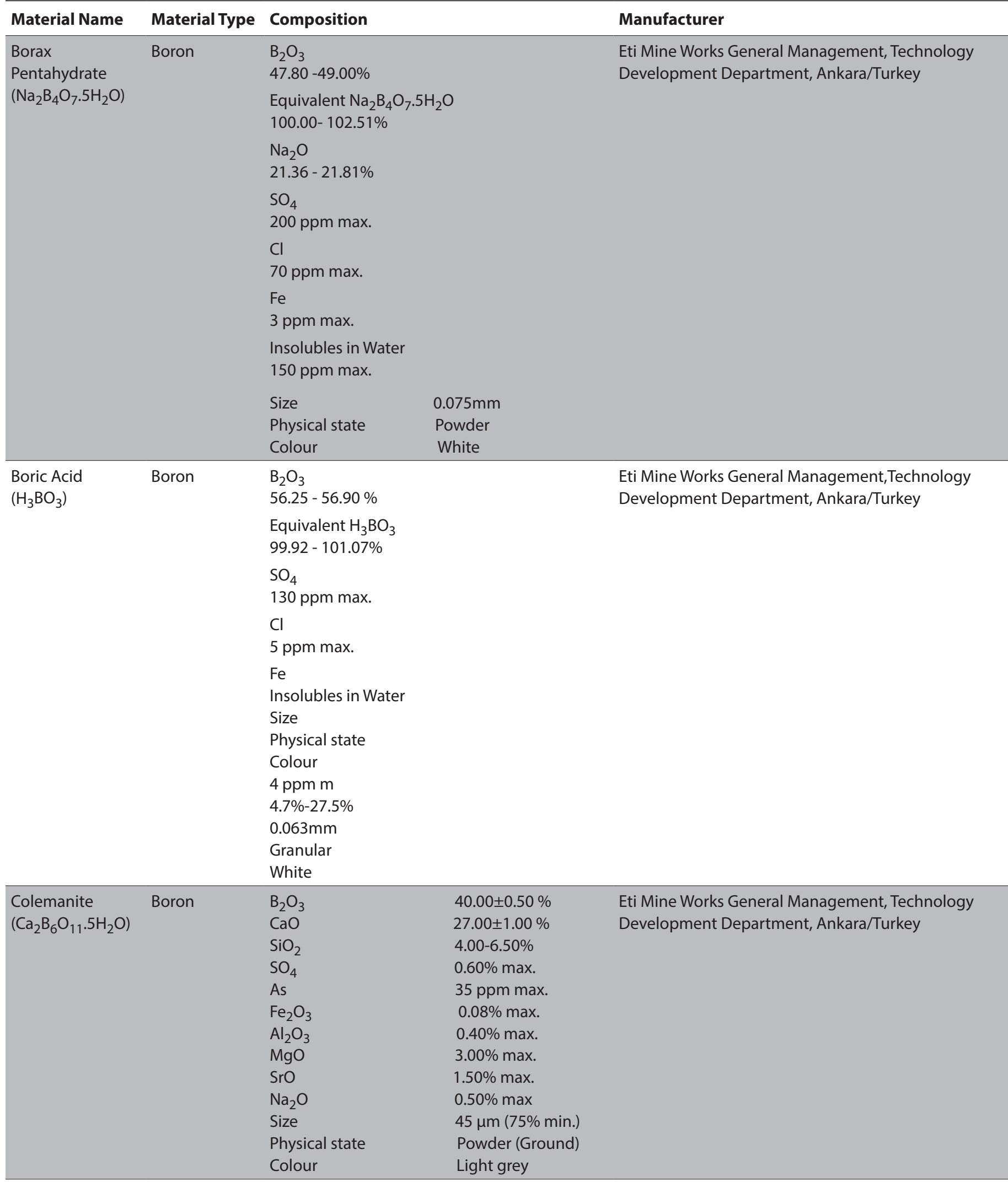

where $a_{\mathrm{cU}}=$ Charpy impact strength of the unnotched specimen $\left(\mathrm{kJ} / \mathrm{m}^{2}\right) ; E c=$ corrected energy absorbed by breaking the test specimen (J); $h=$ thickness of specimen; and $b=$ width of specimen.

Hardness of the specimens was measured with an analog shore D durometer tester (Tronic, Korean). Specimens were measured five times from different area, which was calibrated according to ASTM D2240. The shore value was calculat- ed by averaging the 5 determined values and this process was perform for each specimen.

\section{FTIR and SEM analysis}

The fourier transforms infrared spectrophotometer (FTIR) was used to evaluate the chemical structure differences for 
the PMMA and PMMA samples with added chemicals. The PMMA polymer and PMMA samples with added chemicals were prepared as the Potassium Bromide ( $\mathrm{KBr}$ ) pellets $(2 \mathrm{mg}$ sample in $100 \mathrm{mg} \mathrm{KBr}$ ) and then analyzed in a FTIR (Mattson 1000 , Unicam, USA) at wavelengths between $400-4000 \mathrm{~cm}^{-1}$ and at $4 \mathrm{~cm}^{-1}$ resolution.

Specimens fractured surface evaluated by using Scanning Electron Microscope (SEM) (LEO 440; Zeiss, Oberkochen, Germany). One sample from each experimental group was selected for SEM imaging. $2 \mathrm{~mm}$ cross section was taken from the broken surfaces of the selected samples. The samples were kept in Polaron SC 7620 Sputter Coater until a vacuum of $4 \times 10-2$ mbar was reached and the samples were coated with approximately $45 \mathrm{~A}^{\circ} \mathrm{Au} / \mathrm{Pd}$.

The SEM analysis was performed based on the difference in the polymer matrix among the different boron materials and its distribution based on the different concentrations. Microphotos were captured at 1,000 X standardized magnification for visual inspection and research.

\section{Statistical analysis}

Data was analyzed by using the SPSS 14.0 (SPSS Inc, Chicago). The Kruskal-Wallis and Mann-Whitney $U$ tests were used to compare the different groups. Confidence interval was set to $95 \%$ and $p<0.05$ considered statistically significant.

\section{Results}

Table 2 summarizes the mean values and standard deviations of flexural strength test for all groups. The highest mean flexural strength value was seen in 3\% Boraks group and followed by $1 \%$ Colemanite group. At the other groups, a drop with respect to control group is observed.

In addition, impact strength results including the mean values and standard deviations for all tested specimens are summarized in Table 3. The highest mean impact strength value was recorded in $1 \%$ Colemanite group, and differences between $1 \%$ Colemanite group and control group were found to be statistically significant $(p<0.05)$.
Also, Surface hardness test results including the mean values and standard deviations for all tested specimens are summarized in Table 4. There was significant difference in hardness between control group and all other groups $(p<0.05)$. The highest surface hardness was detected in $2 \%$ Boric acid group and respectively, 2\% Borax, 2\% Colemanite for all percentage intervals.

FTIR spectra of PMMA polymers was carried out by the Fourier transform infrared spectrophotometer (Figure 1). (b), (c) and (d) curves shows borax, boric acide and colemanite added PMMA, respectively, and the (a) curve without any chemical added to PMMA.

According to the FTIR, Boricacid showed difference from the control (in 2328 and 2056) $\mathrm{C}=\mathrm{O}$ pics but didnt changed as chemicaly. On the other hand colemanite and borax showed a chemical changes in the FTIR analysis.

The finger print characteristic frequency of $\mathrm{O}-\mathrm{C}=\mathrm{O}$ stretch at $1717.52 \mathrm{~cm}-1$ and $1432 \mathrm{~cm}^{-1}$ were detected in the spectrum, which could originate from the ester groups in the PMMA and added PMMA side chains $(16,17,18)$. Similar to the other peaks as follows: The bands at $2991.93 \mathrm{~cm}^{-1}$ and 2948.32-2919.35 $\mathrm{cm}^{-1}$ correspond to the $\mathrm{C}-\mathrm{H}$ stretching of the $\mathrm{CH} 3$, methyl group of the PMMA and the irradiated PMMA, the bands at $1382.13 \mathrm{~cm}^{-1}$ and $1432.56 \mathrm{~cm}^{-1}$ were corresponding to the $\mathrm{C}-\mathrm{H}$ symmetric and the asymmetric stretching vibration modes, respectively. The $1236.08 \mathrm{~cm}^{-1}$ frequency vibration was related to $\mathrm{CH} 2$, the methylene group, and the $1137.18 \mathrm{~cm}^{-1}$ frequency vibration band corresponds to the $\mathrm{C}-\mathrm{O}$ ester group. In addition, the $\mathrm{C}-\mathrm{C}$ stretching frequency vibration bands were at $981 \mathrm{~cm}^{-1}$ and $836 \mathrm{~cm}^{-1}$ $(16,18)$. The presence or absence of any other notable peaks were not detected in the spectrum of the PMMA and all borax added PMMA and boric acid added spectra. Except a new peak were detected which has arisen from $\mathrm{CO} 2$ (concerning experimental conditions or preparing $\mathrm{KBr}$ pellets) on boric acid added PMMA (c) at $2318.54 \mathrm{~cm}-1$ and $29156.45 \mathrm{~cm}-1$ and colemanite added PMMA (d) at $2075.29 \mathrm{~cm}^{-1}$. The FTIR findings demonstrate that the addition process does not change the chemical structure of the borax added PMMA and boric acid added PMMA samples. New peaks detected

Table 2. Flexural strength test results of PMMA specimens (MPa)

\begin{tabular}{|c|c|c|c|c|}
\hline & Borax & Boric acid & Colemanite & \\
\hline Control & $103.61 \pm 2.82^{a, b}$ & $103.61 \pm 2.82^{d, e, f}$ & $103.61 \pm 2.82^{1, k}$ & \\
\hline $1 \%$ & $\mathrm{~A}, \mathrm{~B} 91.22 \pm 5.86^{\mathrm{a}, \mathrm{c}}$ & $\mathrm{A}, \mathrm{C} 53.28 \pm 4.73^{\mathrm{d}, \mathrm{g}}$ & $B, C 106.09 \pm 7.38^{1, m}$ & $\begin{array}{c}K W=23.00 \\
P=0.001 \\
P<0.05\end{array}$ \\
\hline $2 \%$ & D,E $100.70 \pm 11.47$ & $\mathrm{D}, \mathrm{F} 56.33 \pm 2.52^{\mathrm{e}, \mathrm{h}}$ & $\mathrm{E}, \mathrm{F} 77.63 \pm 10.02^{1, \mathrm{l}, \mathrm{n}}$ & $\begin{array}{c}K W=24.12 \\
P=0.001 \\
P<0.05\end{array}$ \\
\hline $3 \%$ & $\mathrm{G}, \mathrm{H} 114.38 \pm 11.11^{\mathrm{b}, \mathrm{c}}$ & $G, K 71.86 \pm 10.59^{f, g, h}$ & $\mathrm{H}, \mathrm{K} 88.58 \pm 5.85^{\mathrm{k}, \mathrm{m}, \mathrm{n}}$ & $\begin{array}{c}K W=23.00 \\
P=0.001 \\
P<0.05\end{array}$ \\
\hline & $\begin{array}{c}K W=20.62 \\
P=0.001 \\
P<0.05\end{array}$ & $\begin{array}{c}K W=32.32 \\
P=0.001 \\
P<0.05\end{array}$ & $\begin{array}{c}K W=30.36 \\
P=0.001 \\
P<0.05\end{array}$ & \\
\hline
\end{tabular}

${ }^{*}$ For each vertical column; the same lowercases are significant as statistically $(P<0.05)$, For each horizontal row, the same uppercases are significant as statistically $(\mathrm{P}<0.05)$. 
Table 3. Impact strength test results of PMMA specimens ( $\left(\mathrm{Mm}^{2}\right)$

\begin{tabular}{|c|c|c|c|c|}
\hline & Borax & Boric acid & Colemanite & \\
\hline Control & $4.89 \pm 0.42^{\mathrm{a}, \mathrm{b}, \mathrm{c}}$ & $4.89 \pm 0.42^{\mathrm{d}, \mathrm{e}}$ & $4.89 \pm 0.42^{h}$ & \\
\hline $1 \%$ & A3. $40 \pm 0.77^{\mathrm{a}}$ & ${ }^{B} 4.36 \pm 1.35^{f, g}$ & A,B $6.93 \pm 0.59^{h, k, l}$ & $\begin{array}{c}K W=15.71 \\
P=0.001 \\
P<0.05\end{array}$ \\
\hline $2 \%$ & A $3.27 \pm 0.80^{b}$ & ${ }^{B} 3.01 \pm 0.71^{d, f}$ & $\mathrm{~A}, \mathrm{~B} 4.31 \pm 0.95^{\mathrm{k}}$ & $\begin{array}{c}K W=9.14 \\
P=0.001 \\
P<0.05\end{array}$ \\
\hline $3 \%$ & ${ }^{A} 3.42 \pm 0.66^{C}$ & ${ }^{B} 2.61 \pm 0.69^{e, g}$ & A,B $4.62 \pm 1.02^{\prime}$ & $\begin{array}{c}K W=15.71 \\
P=0.001 \\
P<0.05\end{array}$ \\
\hline & $\begin{array}{c}K W=20.06 \\
P=0.001 \\
P<0.05\end{array}$ & $\begin{array}{c}K W=20.97 \\
P=0.001 \\
P<0.05\end{array}$ & $\begin{array}{c}K W=22.66 \\
P=0.001 \\
P<0.05\end{array}$ & \\
\hline
\end{tabular}

For each vertical column; the same lowercases are significant as statistically $(P<0.05)$. For each horizontal row, the same uppercases are significant as statistically $(P<0.05)$.

Table 4. Surface hardness test results of PMMA specimens

\begin{tabular}{|c|c|c|c|c|}
\hline & Borax & Boric acid & Colemanite & \\
\hline Control & $78.50 \pm 2.36^{a, b, c}$ & $78.50 \pm 2.36^{d, e, f}$ & $78.50 \pm 2.36^{\mathrm{g}, \mathrm{h}, \mathrm{k}}$ & \\
\hline $1 \%$ & $84.60 \pm 3.97^{a}$ & $84.40 \pm 4.00^{\mathrm{d}}$ & $85.70 \pm 2.62^{9}$ & $\begin{array}{c}K W=2.41 \\
P=0.299 \\
P>0.05\end{array}$ \\
\hline $2 \%$ & $87.30 \pm 2.86^{b}$ & $87.60 \pm 2.41^{e}$ & $87.10 \pm 2.02^{h}$ & $\begin{array}{c}K W=0.80 \\
P=0.670 \\
P>0.05\end{array}$ \\
\hline $3 \%$ & $84.70 \pm 4.08^{c}$ & $84.40 \pm 3.20^{f}$ & $85.50 \pm 3.68^{k}$ & $\begin{array}{c}K W=2.41 \\
P=0.299 \\
P>0.05\end{array}$ \\
\hline & $\begin{array}{c}K W=18.59 \\
P=0.001^{*} \\
P<0.05\end{array}$ & $\begin{array}{c}K W=21.57 \\
P=0.001^{*} \\
P<0.05\end{array}$ & $\begin{array}{c}K W=21.24 \\
P=0.001^{*} \\
P<0.05\end{array}$ & \\
\hline
\end{tabular}

*The same lowercases are significant as statistically at the column $(P<0.05)$

around at $2000-2300 \mathrm{~cm}^{-1}$ could be attributed to water and stretching vibrations of atoms in the $\mathrm{C}-\mathrm{O}$ bond of gaseous CO2 sorbed in the samples (19).

It is observed that boron compound bond chemically with acrylic (Figure 1). It can be said that this chemical bond and chemical change increase the strength of the material.

SEM images of acrylic polymer after the impact testing are presented in Fig 2. While Borax observed in the sample with particles had big diameters and consisted of too many particles (Fig 3), small diameters particles and small number of particles were seen in boric acid (Fig 4). In colemanite, it was determined that it dissolves in acrylic due to the absence of particles in SEM images (Fig 5).Compared to other boron components, integration with acrylic composition supports higher values in the Colemanite group. On the other hand, there is no parallel with the percentage change in the Colemanite addition.

\section{Discussion}

The aim of this study is to investigate the changes in the mechanical properties of polymethylmethacrylate when Bo- ron components are added to the acrylic mass in different proportions. Changes in the mechanical properties of polymethylmethacrylate were evaluated by flexural strength, impact strength and surface hardnes tests.

The addition of Borax, Boric acid and Colemanite to polymethylmethacrylate resulted in an increase in surface hardness value. Thus, the null hypothesis was partially accepted.

Fracture strength of denture base resins is of great concern and many approaches have been made to improve the fracture resistance of acrylic resin dentures by strengthening them. Most dentures fracture inside the mouth, primarily due to resin fatigue, with midline fractures being commonly encountered $(20,21)$. Outside the mouth, fracture occurs due to impact of falling. Various modifications have been suggested to overcome these shortcomings, which included plasticization (22), copolymerization with rubber (23), use of crosslinking agents such as polyethylene glycol dimethacrylate and reinforcement with metal strengthener's $(24,25)$. Last two decades has seen a dramatic increase in the use of fiber-reinforced composites with different fibers (26-28). ISO 20795-1 (2008) international standards and ADA (American 


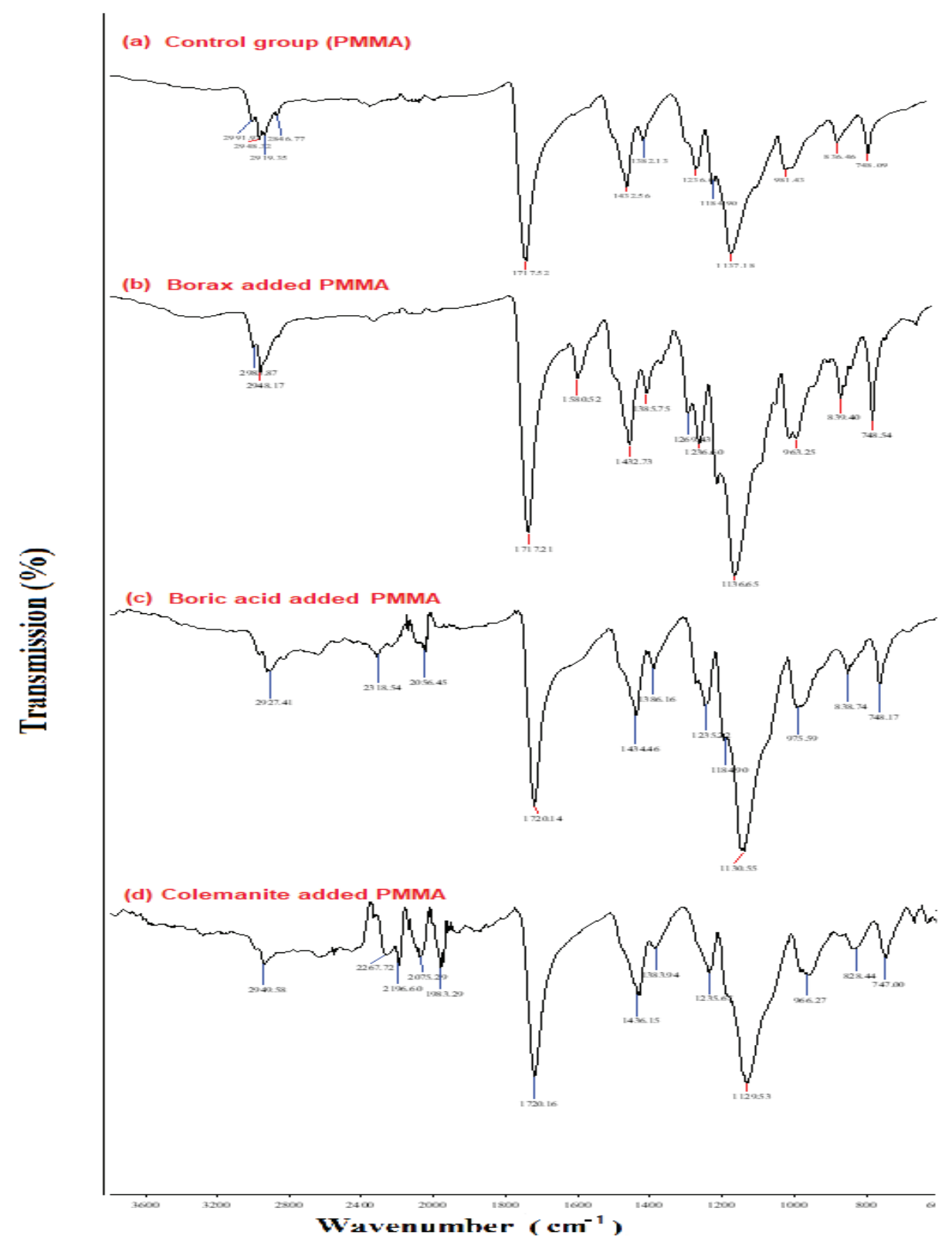

Figure 1. The structural characterization of PMMA samples by an overlapped FTIR spectra (a) Control group (PMMA), (b) Borax added PMMA, (c) Boric acid added PMMA, and (d) Colemanite added PMMA.

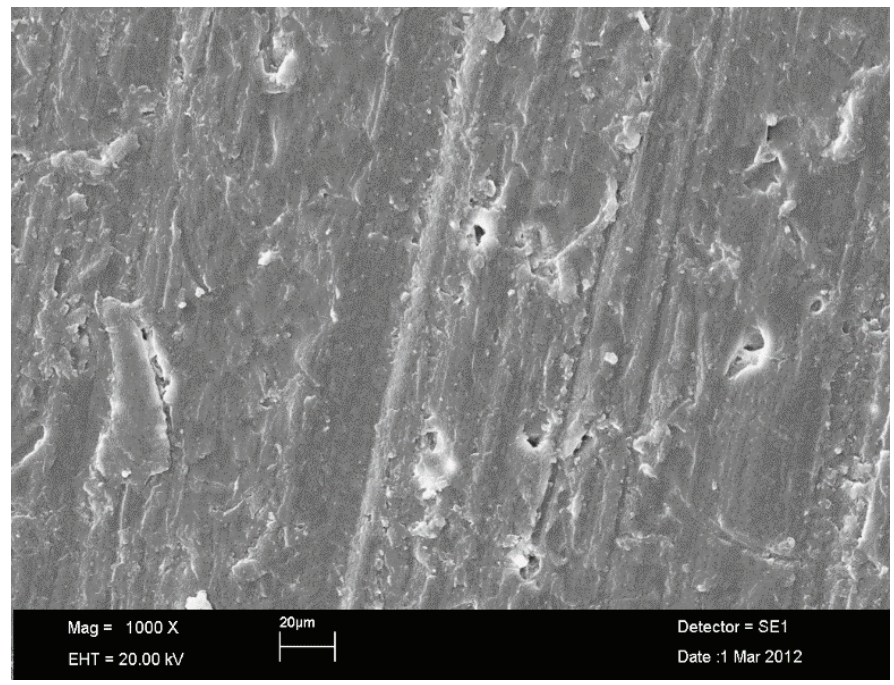

Figure 2. SEM micrograph of PMMA (Control group).

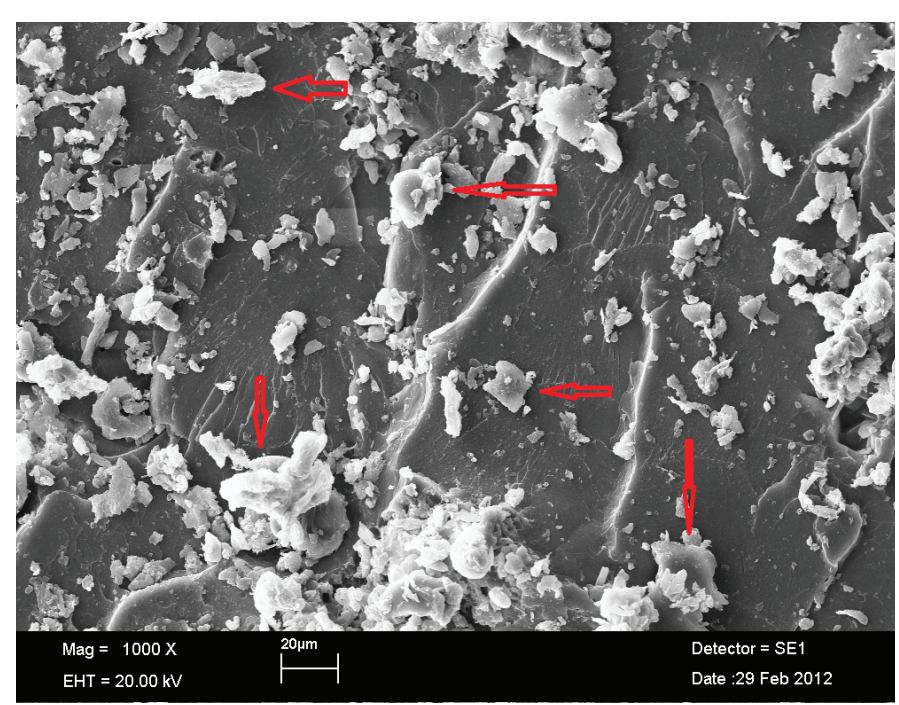

Figure 3. SEM micrograph of Borax added PMMA group. 


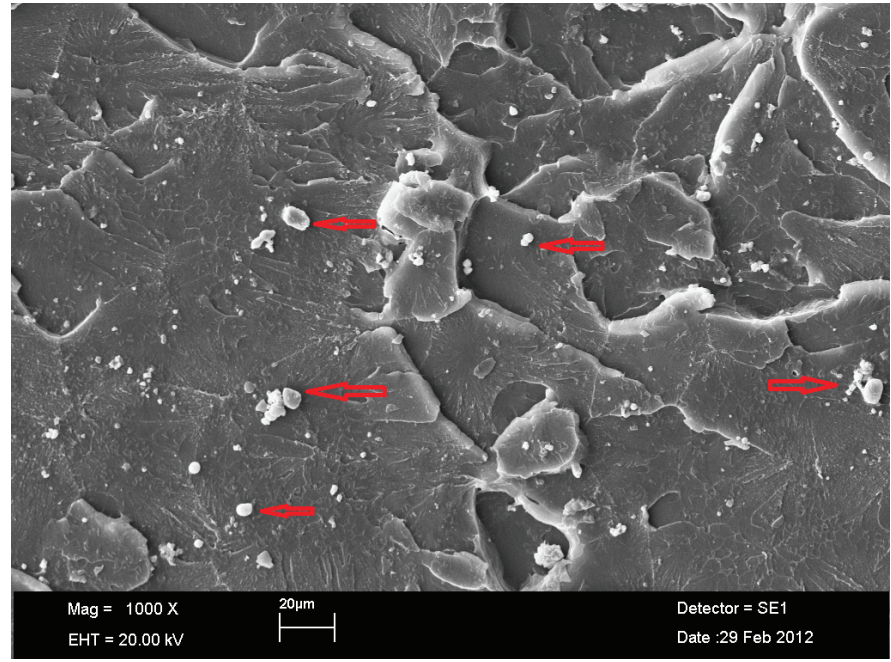

Figure 4. SEM micrograph of Boric acid added PMMA group.

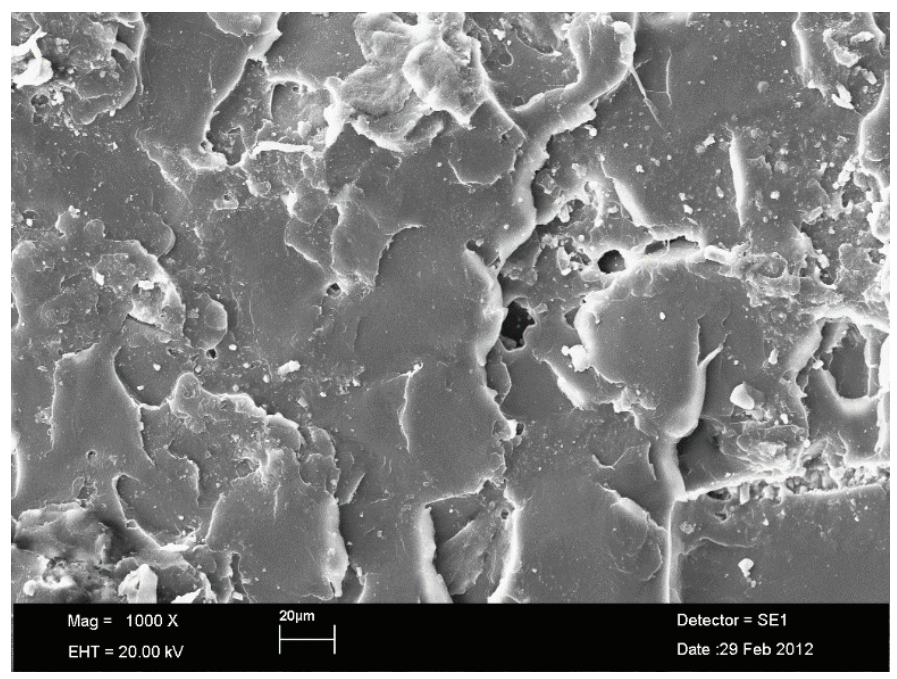

Figure 5. SEM micrograph of Colemanite added PMMA group.

Dental Association) standart have established respectively $50 \mathrm{MPa}$ and $65 \mathrm{MPa}$ as the minimum flexural strength required of all acrylic resins used for denture bases $(15,29)$.

We added in certain proportions considering that the boron is as durable as a diamond will increase the impact strength of PMMA (11). It is known that boron is an essential element for humans and animals. Boron play important roles in many life processes including embryogenesis, bone growth and maintenance, immune function and psychomotor skills. However, it is indicated that boron compounds have bacteriostatic, bactericidal, fungistatic, fungicidal and antiviral effects and it is highly biocompatible (30).

In this study, it is seen that the flexural and impact strength of the polymethylmethacrylate is affected independently of both the added boron component and the boron component addition percentage. However, while different kind of boron had significantly different effects on the mechanical properties of PMMA, for the purpose of strengthening acrylic structure created the biggest effect at flexural and impact resistance of $1 \%$ Colemanite group. Finally, the addition of $1 \%$ Colemanite to PMMA improved the mechanical properties of PMMA.

In this study, the highest flexural strength values were observed in the 3\% Borax group (114.38 MPa) and 1\% Colemanite group (106.09 $\mathrm{MPa}$ ), the lowest flexural strength value in the $1 \%$ Boric acid group (53.28 MPa). All values ob- tained did not fall below the value specified in ISO standards.

Mean impact strength values were lower than the control group in all experimental groups except 1\% Colemanit group. The highest mean impact strength value was recorded in 1\% Colemanite group (6.93 MPa), and differences between $1 \%$ Colemanite group and control group (4.89 MPa) were found to be statistically significant $(p<0.05)$.

These results indicate that the most ideal composition of polymethylmethacrylate components and boron compounds is achieved by adding $1 \%$ Colemanite.

Unfortunately, efforts to find the ideal material to reinforce the acrylic is still continuing. Boron derivatives such as Borax, Boric Acid, and Colemanite is commonly used as inorganic binder in the ceramic industry. They reduce the viscosity and surface tension, and that provide resistance to cracking and surface staining $(31,32)$. However, there are not readily available in the literature, investigating the effect of these compounds on mechanical and chemical properties of acrylic material; therefore, it was not possible to compare the results of the present study and those of previous similar studies. Because of the lack of study with boron to strengthen the acrylic, filler and nano-filler addition studies were compared.

Arora et al. reviewed the effect of alumina addition and reported a positive impact on the properties of acrylic resin (33).

There are other studies reporting that the addition of metal oxides reduces both impact and tensile strength of PMMA, although there are studies reporting that the resin has increased bending strength, impact strength, tensile strength, compressive strength, and surface hardness after the addition of metal oxides. The positive and negative changes in the mechanical properties of PMMA have been explained because of the stress concentration around the embedded metal and its poor adhesion to the polymer (34-37).

The superior properties of nano-diamonds, high hardness and thermal conductivity suggested that it can be used to improve the mechanical properties of PMMA. Al-Harbi et al. reported that the addition of nano-diamond to acrylic denture base improved the flexural strength and surface roughness at low concentrations while impact strength was decreased (38). The researchers interpreted that the addition of high concentrations of nano-diamond negatively affects the mechanical properties of the polymethylmethacrylate, as nano-diamonds may have been collected as stress concentration points $(38,39)$.

Boron compounds can also be considered as a filler material. The reason for the different results in this study may have changed in relation to how concentrated the boron components are in the fracture line.

In this study Borax, Boric Acid, Colemanite was added to heat-polymerized denture base resin at volume ratios of $1 \%$, $2 \%$ and $3 \%$ and the reinforcing effects depending on the boron type and concentration were evaluated. The flexural properties of denture base resin showed significant differences depending on the various combinations and concentrations of the three boron. Addition of $1 \%$ Colemanite to PMMA improved the mechanical properties of PMMA. There was an increase in surface hardness in all groups. The structural characterization of boron added PMMA by Fourier Transform Infrared Spectrophotometry showed that there were chemical changes in Colemanite and Borax group. 
The SEM image of the fracture surface of the control group was smoother, while the $1 \%$ colemanite sample images with the highest flexural and impact values showed a more roughened structure. On the images of borax and boric acid, undissolved particles that may cause porosity in the structure were observed. We think that this maybe negatively affect the resistance. It is advisable to reinforce the denture with $\% 1$ colemanite because of its positive impact and flexural resistance capability. Further work is clearly required to investigate the effect of colemanite on PMMA.

SEM images confirmed the unreinforced PMMA had a sharp crack surface without visible plastic deformation. With the addition of $\% 1$ colemanite, uniform multi-stepped morphology was observed (Fig 5), increased the impact and flexural strength of PMMA.

The current study is limited by its an in vitro study, it does not accurately simulate intraoral conditions and predicting the clinical behavior of the material can be difficult. Therefore, in addition to further in vitro studies, clinical studies are also required.

\section{Conclusion}

Within the limitations of this study, the following conclusions can be drawn:

- $\quad$ PMMA impact strength increases with the addition of $\% 1$ colemanite.

- The increase in flexural strength of PMMA is greater with the addition of $3 \%$ Borax when compared to 1 $\%$ Colemanite

- Borax increased the surface hardness of PMMA denture base resin.

Finally, when high strength acrylic resins are needed, boron reinforced resins may be the material of choice.

Türkçe Özet: Borun Polimetilmetakrilat Protez Kaide Materyalinin Mekanik Özellikleri Üzerine Etkileri. Amaç: Bu çalışmanın amacı farkıı boron tiplerinin (Boraks, Borik Asit ve Kolemanit) ilavesinin, kaide materyali olarak kullanılan polimetilmetakrilatın bükülme, darbe dayanımlarını ve yüzey sertliğini artırıp artırmayacağının araştırılmasıdır. Gereç ve Yöntemler: Üreticilerin talimatlarına göre ısı ile polimerize edilmiş polimetil metakrilata Boraks, Borik asit, Kolemanit ilave edilmiştir. Bükülme testi için $(65 \times 10 \times 2.5 \mathrm{~mm})$, darbe dayanımı testi için $(50 \times 6 \times 4 \mathrm{~mm})$ ve sertlik testi için $(20 \times 6 \times 4 \mathrm{~mm})$ boyutlarında örnekler hazırlanmıştır ( $n=$ 10). Örneklerin bükülme dayanımını ölçmek için universal test cihazında üç nokta eğme testi ile kırılana kadar kuvvet uygulanmıştır. Darbe dayanımı testi için Charpy test cihazı kullanılmıştır. Örneklerin sertliği Shore $D$ analog shoremetre ile ölçülmüştür. Veriler Kruskal-Wallis ve Mann-Whitney U testleri ile analiz edilmiştir $(a=0.05)$. Bulgular: En yüksek bükülme dayanımı \% 3'lük Boraks grubunda görülmüş ve bunu \% 1 Kolemanit grubu takip etmiştir. Ayrıca en yüksek darbe dayanımı \% 1 Kolemanit grubunda görülürken \% 1'lik Kolemanit grubu ile kontrol grubu arasındaki farklar istatistiksel olarak anlamlı bulunmuştur ( $p=0,001)$. Ayrıca, kontrol grubu ile diğer tüm gruplar arasında yüzey sertliği açısından istatistiksel olarak anlamlı bulunmuştur $(p<0,001)$. Sonuç: Polimetilmetakrilata \% 1 Kolemanit ilavesi PMMA'nın mekanik özelliklerini geliştirmiştir. Anahtar Kelimeler: Polimetilmetakrilat, Bor, Bükülme dayanımı, Darbe dayanımı, Yüzey sertliği

Ethics Committee Approval: This study was approved by the Clinical Research Ethics Committee of Cumhuriyet University, Sivas. (2021-01/25).

Informed Consent: Participants provided informed constent.
Peer-review: Externally peer-reviewed.

Author contributions: AKO designed the study. DOD, FT and HD participated in generating the data for the study DOD and FT participated in gathering the data for the study. HA participated in the analysis of the data. DOD and FT wrote the majority of the original draft of the paper. FT participated in writing the paper. All authors approved the final version of this paper.

Conflict of Interest: I certify that all my affiliations with or financial involvement in, within the past 5 years and foreseeable future, any organization or entity with a financial interest in or financial conflict with the subject matter or materials discussed in the manuscript are completely disclosed (e.g. employment, consultancies, honoraria, stock ownership or options, expert testimony, grants or patents received or pending, royalties). Authors have no financial interests related to the material in the manuscript.

Financial Disclosure: The authors gratefully acknowledge the financial support provided by the Scientific Research Project Fund of Cumhuriyet University Project DIS-078.(01.06.2010)

\section{References}

1. Rickman LJ, Padipatvuthikul P, Satterthwaite JD. Contemporary denture base resins: Part 1. Dent Update 2012;39:25-8. [CrossRef]

2. Gad MM, Fouda SM, Al-Harbi FA, Näpänkangas R, Raustia A. PMMA denture base material enhancement: a review of fiber, filler, and nanofiller addition. Int J Nanomedicine 2017;17:3801-12. [CrossRef]

3. Vallitlu PK. A rewiew of fiber reinforced denture base resins. J Prosthodontics 1996;5:270-6. [CrossRef]

4. Kim SH, Watts DC. The effect of reinforcement with woven E-glass fibers on the impact strenght of complete dentures fabricated with-high-impact aciylig resin. J Prosthet Dent 2004;91:274-80. [CrossRef]

5. Jagger DC, Harrison A, Jandt KD. The reinforcement dentures. J Oral Rehabil 1998;26:185-94. [CrossRef]

6. Cökeliler D, Erkut S, Zemek J, Biederman H, Mutlu M. Modification of glass fibers to improve reinforcement: a plasma polymerization technique. Dent Mater 2007;23:335-42. [CrossRef]

7. Franklin P, Wood DJ, Bubb NL. Reinforcement of poly(methyl methacrylate) denture base with glass flake. Dent Mater 2005;21:365-70. [CrossRef]

8. Kanie T, Arikawa H, Fujii K, Ban S. Flexural properties of denture base polymers reinforced with a glass cloth-urethane polymer composite. Dent Mater 2004;20:709-16. [CrossRef]

9. Lee HK, Zerbetto S, Colombo P, Pantano CG. Glass-ceramics and composites containing aluminum borate whiskers. Ceram Int 2010;36:1589-96. [CrossRef]

10. Zhang X, Zhang X, Zhu B, Lin K, Chang J. Mechanical and thermal properties of denture PMMA reinforced with silanized aluminum borate whiskers. Dent Mater J 2012;31:903-8. [CrossRef]

11. Nkambule SM, Lowther JE. Crystalline and random "diamondlike" boron-carbon structures. Solid State Communic 2010;150:133-6. [CrossRef]

12. Roskill, "The Economics of Boron", 9th edition, 1999.

13. Akturk E, Bektas OO, Ozkanoglu S, Akin EGG. Do Ozonated Water and Boric Acid Affect the Bond Strength to Dentin in Different Adhesive Systems ? Niger J Clin Pract 2019;22:1758-64. [CrossRef]

14. Prentice LH, Tyas MJ, Burrow MF. The effects of boric acid and phosphoric acid on the compressive strength of glass-ionomer cements. Dent Mater 2006;22:94-7. [CrossRef]

15. Revised American Dental Association specification no. 12 for denture base polymers. J Am Dent Assoc 1975;90:451-8. [CrossRef]

16. Schulzea KA, Marshalla SJ, Ganskyb SA, Marshalla GW. Color stability and hardness in dental composites after accelerated aging. Dent Mater 2003;19:612-19. [CrossRef] 
17. Fraunhofer JA, Curtis PM Jr, Sharma S, Farmam AG. The effects of gamma radiation on the properties of composite restorative resins. J Dent 1989;17:177-83. [CrossRef]

18. Dogan DO, Ozguven Y, Karakus G, Sahin O, Polat NT, Yucel B, Dogan M. The effects of therapeutic x-ray doses on mechanical, chemical and physical properties of poly methyl methacrylate. Acta Odontologica Scandinavica, 2013;71:45-9. [CrossRef]

19. Akgul Ö, Acarali NB, Tugrul N, Derun EM, Piskin S. X-Ray, Thermal, FTIR and morphological studies of zinc borate in presence of boric acid synthesized by ulexite. Periodico di Mineralogia 2014; 83:77-88.

20. Smith DC. Recent developments and prospects in dental polymers. J Prosthet Dent 1962;12:1066-78. [CrossRef]

21. Stafford GD, Smith DC. Flexural fatigue tests of some denture base polymers. Br Dent J 1970;128:442-5. [CrossRef]

22. Chander NG. Polymethyl metha acrylate denture base: An overview. J Indian Prosthodont Soc 2018;18:87-8. [CrossRef]

23. Stafford GD, Bates JF, Hugget R, Handley RW. A review of the properties of some denture base polymers. J Dent 1980;8:292306. [CrossRef]

24. Ruffino AR. Effect of steel strengtheners on fracture resistance of acrylic resin complete denture base. J Prosthet Dent 1985;54:758. [CrossRef]

25. Vallittu PK, Lassila VP. Reinforcement of acrylic resin denture base material with metal or fiber strengtheners. J Oral Rehabil 1992;19:225-30. [CrossRef]

26. Kumar GV, Nigam A, Naeem A, Gaur A, Pandey KK, Deora A. Reinforcing Heat-cured Poly-methyl-methacrylate Resins using Fibers of Glass, Polyaramid, and Nylon: An in vitro Study. J Contemp Dent Pract 2016;17:948-52. [CrossRef]

27. Rahamneh A, Jagger DC, Harrison A. The effect of the addition of different fibres on the transverse and impact strength of acrylic resin denture base material. Eur J Prosthodont Restor Dent 2003;11:75-81.

28. Yu SH, Lee Y, Oh S, Cho HW, Oda Y, Bae JM. Reinforcing effects of different fibers on denture base resin based on the fiber type, concentration, and combination. Dent Mater J 2012;31:1039-46. [CrossRef]
29. ISO: Dentistry - Base polymers Part 1: Denture base polymers. 1st ed. Geneva, Switzerland: International Organization for Standardization, ISO 20795-1; 2008.

30. Sağlam M, Köseoğlu S, Enhoş Ş. Boron in Periodontology. J of Health Sci 2013;22:70-75.

31. Cengiz Ö, Kara A. Effects of boric acid addition on sintering behaviour of single-fired wall tile bodies. AKU- J Sci 2012; Special issue: 29-35.

32. Bilgin AM, Gökmeşe H, Bostan B. Production of electro porcelain reinforced with boric acid and investigation of its properties. J Fac Eng Archit Gaz 2015;30:577-83. [CrossRef]

33. Arora P, Singh SP, Arora V. Effect of alumina addition on properties of polymethylmethacrylate - a comprehensive review. Int J Biotech Trends Technol 2015;9:1-7.

34. Asar NV, Albayrak H, Korkmaz T, Turkyilmaz I. Influence of various metal oxides on mechanical and physical properties of heat-cured polymethylmethacrylate denture base resins. J Adv Prosthodont 2013;5:241-7. [CrossRef]

35. Ellakwa AE, Morsy MA, El-Sheikh AM. Effect of aluminum oxide addition on the flexural strength and thermal diffusivity of heat-polymerized acrylic resin. J Prosthodont 2008;17:439-44. [CrossRef]

36. Abdulhamed AN, Mohammed AM. Evaluation of thermal conductivity of alumina reinforced heat cure acrylic resin and some other properties. J Bagh Coll Dent 2010;22:1-7.

37. Vojdani $M$, Bagheri $R$, Khaledi AR. Effects of aluminum oxide addition on the flexural strength, surface hardness, and roughness of heat-polymerized acrylic resin. J Dent Sci 2012;7:238-44. [CrossRef]

38. Al-Harbi FA, Abdel-Halim MS, Gad MM, Fouda SM, et al. Effect of Nanodiamond Addition on Flexural Strength, Impact Strength, and Surface Roughness of PMMA Denture Base. J Prosthodont 2019;28:417-25. [CrossRef]

39. Dolmatov VY. Polymer-diamond composites based on detonation nanodiamonds: Part 2. J Superhard Mater 2007;29:65-75. [CrossRef] 